\section{日本臨床外科学会滋賀県支部抄録 （第116回滋賀県外科医会）}

\author{
日 時：令和元年11月30日（土） \\ 午後 1 時 午後 6 時 \\ 会 場：ピアザ淡海 県民交流センター $3 \mathrm{~F}$ \\ 305号会議室
}

支部長：日野記念病院 外科 花澤一芳

\section{特別講演}

座長 滋賀医科大学 外科学講座 谷 眞至 「低侵襲胃癌手術の現状と今後の展望」

山梨大学 外科学講座第 1 教室

\section{教授 市川 大輔}

1 ロボット支援下胃切除術の腹腔鏡下胃切除術との比較 における安全性の検討

滋賀医科大学外科学講座

貝田佐知子、竹林克士、石川 健、塩見一徳、前川 毅、徳田 彩、 児玉泰一、伊藤 文、前平博充、小島正継、植木智之、三宅 亨、 飯田洋也、山口 剛、谷 眞至

ロボット支援下手術は鉗子の多関節機能、高解像度 $3 \mathrm{D}$ モニター、 緻密性を特徴とし、当院ではロボット支援下胃切除術（RG）を 2017年より導入している。従来の腹腔鏡下胃切除術 (LG) との 比較を行い、RGの安全性を検討した。【方法】2011年 1月～2019 年10までに胃癌に対して施行したRG 33例と LG 169例の短期成 績につき検討した。【結果】 RG 群と LG 群を比較したところ、患 者背景 (年齢、性別、BMI)、術式、手術時間、術後在院日数、 Clavien-Dindo Grade II 以上の術後合併症発症率に有意差を認め なかった。出血量はRG 群がLG群と比較して有意に少なかった (中央值 $20 \mathrm{ml} v \mathrm{vs} 100 \mathrm{ml}, \mathrm{p}<0.001$ )。リンパ節郭清個数はRG 群 で多い傾向にあった（中央值 RG：35個 [14〜71] vs LG：30個 [9 ～68], $\mathrm{p}=0.139)$ 。RGにおいて開腹移行症例はなかった。【結語】 RGはLGと比較して出血量が有意に少なく、合併症や手術時間、 在院日数に有意差を認めず、安全性において有用であることが示 唆された。

\section{2 当院における直腸脱手術の現状}

彦根市立病院外科

崎久保守人、岡村 見、神頭 聡、龍見謙太郎、川部 篤、安田 誠一

2010年 1 月から 2019年11月までの約10年間の直腸脱手術 27 例に対 して検討を行なった。1 例を除き全て女性で、年齢は 57 ～97歳 (平 均84.2歳）であった。期間前半の術式は、ほぼGan-MiwaThiersch法 $(11 / 13)$ だが、後半はAltemeier 法が半数程度 (8 ／14）であった。脱出腸管長は、それぞれ平均 $4.7 \mathrm{~cm}$ 、平均 6.4 $\mathrm{cm}$ で後者が長い傾向にあった。手術時間はそれぞれ平均 43 分、 平均89分で後者が有意に長かった。在院日数はともに 8.2 日であ つた。再発に対して手術した症例ならびに本検討内で 3 名が再発 し重複していたため、24患者中 6 名に何らかの再発があったこと になる。腹腔鏡下縫合直腸固定術を再発の 2 例に対して施行した。 手術時間は 4 時間前後で在院日数は平均 13 日、合併症、再発は認 めなかった。今後、術式選択基準について慎重に検討したい。
3 右半結腸非閉塞性壊死症の 1 例

近江八幡私立総合医療センター外科

川脇拓磨、武内悠馬、瀧本篤郎、嶋村 藍、大坂雅史、荒谷憲一、 門谷弥生、中野且敬、秋岡清一、土屋邦之

症例は66歳の女性。腹痛を主訴に精神科病院からショック状態で 救急搬送された。造影 CT 検査では、明らかな閉塞や血栓は認め なかったが、右半結腸に著明な浮腫性変化と造影不良域、肝内門 脈内気腫を認めた。非閉塞性腸管虚血（non- occlusive mesenteric ischemia, NOMI）を疑い、急性腹症として緊急手術を施行 した。術中に盲腸から右側横行結腸までの非連続性の壊死領域を 認め、壊死領域の支配血管の拍動は触知良好であった。右半結腸 切除後、機能的端々吻合を施行した。術後有害事象はなく経過は 良好で、第15病日に元の精神科病院へ転院した。切除腸管の病理 検査では、動脈の閉塞や血栓はなく、壊死部に血管炎を認めた。 血管炎が発症に関与していたと疑われ、病理検查が再発防止の治 療戦略に有用であったと考えられた。

\section{4 シートベルト外傷による結腸穿孔の 1 例}

草津総合病院消化器外科

一瀬真澄、藤城直宣、大江康光、小座本雄軌、基 俊介、戸川 剛、 高尾信行、水本明良、平野正満

症例は20歳代、男性。主訴は左下腹部痛。2019年 6 月、軽自動車 の助手席に乗車中、交差点内に進入、右折をしょうとして直進の トラックと衝突した。軽自動車は横転し、当院に救急搬送される。 シートベルト着用、エアバック作動。左下腹部痛あるも外傷なし。 腹部造影 CT で骨盤底に血性腹水を指摘。腸間膜損傷による腹腔 内出血と診断し、入院となる。入院 2 日目飲水開始。入院 3 日目 流動食を開始するもその後腹痛があり、腹部 CTを再度撮影。腹 部全体に拡がるフリーエアーがあり、消化管穿孔として緊急手術 を行った。腹腔鏡で腹腔内を観察すると、左下腹部の腸管が腹壁 と強く癒着しており、これを剥離すると $\mathrm{S}$ 状結腸の穿孔がみつか った。周囲に便汁の漏れは見られなかった。開腹手術に移行し、 S 状結腸の部分切除を行った。術後経過は順調で術後 9 日目に軽 快退院した。腹部の鈍的外傷の腸管損傷は小腸が多いが大腸なと ほかの臓器の可能性もあり、慎重な評価が重要となる。

\section{5 当院における高齢者乳癌症例の検討}

公立甲賀病院外科

森毅、岸 和樹、岡田俊裕、岡村裕輔、中右雅之、池田房夫 近年、乳癌は増加傾向にあり、高歯化に伴い高齢者乳癌も増加し ている。乳癌診療ガイドラインでは、高齢者乳癌に対し手術療法、 標準的な術後補助療法が推奨されているが、併存疾患などから標 準的治療を遂行できないことも多い。今回われわれは、当院で診 断された80歳以上の原発性乳癌について検討した。年齢の中央值 は86歳で、病期は、 $0 ： 2$ 例、I $: 6$ 例、II A $: 12$ 例、II B $: 1$ 例、 III A：2 例、 III B : 3 例、IV : 1 例で、手術施行症例が20例、薬 物療法のみが 6 例、無治療 1 例であった。手術症例 20 例中 17 例に、 何らかの併存疾患を認めたが、術後合併症はみとめなかった。薬 物療法に関しては、ホルモン受容体陽性20例中19例に、内分泌療 法が施行されていた。3例に経口抗癌剂の投薬がされていたが、 2 例は有害事象で中止を余儀なくされていた。80歳以上の高齢者 乳癌患者は併存疾患を有することが多く、Stage、サブタイプ、 PSなどを考慮しながら治療を行う事が重要であると考えられた。 
6 当院における膵頭十二指腸切除術の術後短期成績 長浜赤十字病院外科

東口貴之、塩見尚礼、村本圭史、長門 優、谷口正展、園田寛道、 丹後泰久、張 弘富、中村一郎、中村誠昌

膵頭十二指腸切除術は、安全に施行されるようになったとはいえ、 消化管手術に比べると、死亡率は依然高い。この死亡率を左右す るのが術後合併症、とくに膵液漏と、それに続く腹䏶内出血、敗 血症である。当院では膵頭十二指腸切除術の再建に際し、 Blumgart変法で膵腸吻合を行っており、その成績について報告 する。症例は、2015年11月から2019年 5 月までの間に膵頭部領域 疾患に対して行った膵頭十二指腸切除術施行症例38症例。性別は 男性22症例、女性16症例。平均年齢は68.1歳（39～85歳）。疾患は、 膵頭部癌 27 例、胆道癌 10 例、慢性膵炎 1 例。術式は、胃切除の既 往のある 1 症例のみ膵頭十二指腸切除術、他は亜全胃温存膵頭 十二指腸切除術を施行した。執刀医は 4 名であった。平均手術時 間は504分で、平均出血量は981.2 ml。Grade B以上の膵液瘦は $13.2 \%$ \%った。

7 病理組織学的視点に基づく正常膵に対する安全かつ機 能的な膵空腸吻合法の提案

大津市民病院外科

藤田覇留久、大江秀典、植村泰佑、岡部あさみ、青山太郎、平井 健次郎、橘強、光吉 明

正常膵ではその切断面のほとんどを膵液産生旺盛な腺房細胞が占 め、細膵管などの分枝膵管が断面の隅々まで発達している。主膵 管と同様、分枝膵管からの膵液も腹腔内に漏らすことなく再建で きる方法として、従来の二列法（膵実質空腸漿膜筋層縫合）を基 本とし、主膵管の完全外瘦化および膵管空腸粘膜綘合を両立させ た術式を考案した。2013～2018年に当院で施行した膵頭十二指腸 切除術52例中、20例において本術式を行った。術後膵液瘦は Grade A 5 例, Grade B 0 例 Grade C 1 例であった。【結語】 膵管および腺房細胞の分布に関する病理組織学的見地から、正常 膵の膵空腸吻合における POPFの予防と膵管開存性の維持を両立 しうる吻合法を提案した。今のところ良好な結果を得ているが、 さらに症例を重ねた上での検討が必要である。

\section{8 膵頭十二指腸切除術における膵空腸吻合の工夫}

大津赤十字病院外科

中山雄介、豊田英治、吉村昂平、安宅 亮、岡田奈月、多賀 亮、 甲津卓実、金田明大、松林 潤、北口和彦、池野嘉信、伊藤達雄、 浦 克明、大江秀明、廣瀬哲朗、土井隆一郎

膵液漏は膵頭十二指腸切除術の術後合併症として、最も注意が必 要な合併症である。その予防のために様々な膵再建法が存在する。 当院では、膵再建は膵空腸吻合、吻合法は膵管粘膜吻合を採用し ている。2014年11月～2019年11月の期間に施行した膵頭十二指腸 切除術135例の手術時間、出血量、在院日数の中央值は 482 分、 $480 \mathrm{ml}$ 、23日であった。Grade Bの膵液漏は13例（10\%）あった が、Grade Cの膵液漏は認めなかった。Clavien-Dindo Grade III a 以上の合併症を17例（13\%）に認めたが、周術期死亡はゼロで あった。当院での膵空腸吻合の工夫を実際の手術動画と共に紹介 する。
9 吻合手技

大津赤十字病院外科

豊田英治、北口和彦、安宅 亮、岡田奈月、多賀 亮、吉村昴平、 甲津卓実、金田明大、松林 潤、中山雄介、池野嘉信、伊藤達雄、 浦 克明、大江秀明、廣瀬哲朗、土井隆一郎

当院では2018年 3 月から、腹腔鏡下膵頭十二指腸切除 $(L a p-P D)$ を保険診療として臨床導入し、2019年 8 月までに15例を経験した。 Lap-PDの膵空腸吻合手技をビデオで供覧し、短期手術成績を報 告する。膵は電気メス、超音波凝固切開装置で離断し、主膵管を 含む中央部は剪刀で切離する。空腸を結腸後経路で挙上し、空腸、 膵へ運針のマーキングを行った後、吻合を開始する。現在は体腔 内でのBlumgart変法を行っており、外層の膵空腸密着縫合は、 丸針弱弱弱弯 4-0 非吸収系、内層は膵管空腸全層縫合を 5-0 非 吸収糸 4 針で行い、 $4 \mathrm{Fr}$ 膵管チューブをロストステントとして 留置している。この体腔内膵空腸吻合を行った 7 例の膵空腸吻合 時間の中央值は88分、手術出血量中央值は392 mlであった。膵 液瘦はGrade A (biological leak) が6例で、Grade B以上の膵 液瘦は認めなかった。Clavien-Dindo分類では、II が 3 例で、III $\mathrm{a}$ 以上の症例は認めなかった。当科で採用している体腔内膵空腸 吻合の成績は良好であると考える。 